\title{
Peranan Pendidikan Agama Islam Dalam Menumbuhkan Kecerdasan Emosional
}

\author{
Oleh: Andi Makmur Jaya Nur ${ }^{1}$
}

$* * *$

\begin{abstract}
Abstrak
Tidak dapat dipungkiri bahwa praktek pendidikan diarahakn untuk mewujudkan manusia-manusia cerdas. Lewat kecerdaan tersebut, mereka diharapkan untuk menjadi inovatif dan kreatif untuk mengisi pembangunan negara. Harapan ini tentu bukanlah isapan jempol karena memang pendidikan di negara manapun dilaksanakan dengan berbagai macam pendekatan dan sistem untuk memenuhi akselerasi perkembangan zaman. Bahkan output pendidikan menjadi komponen utama dalam akselerasi zaman tersebut. Hasilnya, setiap negara termasuk Indonesia "berhasil" mewujudkan manusia-manusia cerdas untuk mengawal pembangunan bangsa dan negara. Cendekiawan, elit politik-negara, teknokrat dan berbagai macam profesi telah berhasil ditelorkan dunia pendidikan. Jadi, tidak berlebihan jika dikatakan bahwa pendidikan dengan pembangunan merupakan dua sisi mata uang yang satu; tidak dapat terpisahkan. Jika pendidikan berhasil, maka negara pun akan berhasil.

Namun demikian, dalam konteks Indonesia, pendidikan dengan berbagai sistem dan bentuknya cukup menjanjikan. Tidak hanya negara, tetapi pihak-pihak swasta pun menyelenggarakan pendidikan untuk demi pencerdasan anak-anak bangsa. Tetapi fenomena paradoksal pun terlihat. Tawuran peserta didik semakin semarak, "kebocoran" anggaran kenegaraan semakin membengkak, dan masih banyak lagi fenomena sosial yang terjadi yang notabene dilakukan oleh orang-orang terdidik. Apakah pendidikan tidak membuat mereka cerdas? Jika di telaah, pendidikan yang diselenggarakan dewasa ini sangat intens untuk membuat peserta didik menjadi cerdas. Mereka dapat meraih juara pada setiap momen kejuaraan. Hanya saja, pendidikan yang terselenggara tampaknya lebih menekankan pada aspek pencerdasan intelektual, tetapi sedikit mengabaikan pencerdasan emosional bahkan spriritual.
\end{abstract}

Kata Kunci: Pendidikan, dan Kecerdasan Emosional

${ }^{1}$ Dosen STAIM Sinjai 


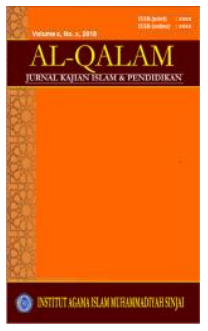

AL-QALAM

Jurnal Kajian Islam \& Pendidikan

Volume 06 No 012014

ISSN (print) : 1858-4152

ISSN (online) : -

Homepage : http://journal.iaimsinjai.ac.id/index.php/al-qalam

\section{PENDAHULUAN}

$\mathrm{K}$

emajuan teknologi saat sekarang ini, berkembang dengan sangat pesatnya. Salah satu faktor yang banyak berperan dalam era kecangihan teknologi sekarang ini adalah lahirnya sistem digital. Melalui sistem digital, berbagai bidang teknologi terlahir dan mengalami kemajuan yang luar biasa, seperti komputer, software, telekomunikasi hingga penerbangan luar angkasa.

Teknologi digital muncul di era modern ini setelah ditemukannya bilangan biner, yaitu angka nol dan satu sebagai sistem transformasinya. Tak ayal lagi, semua sisi kehidupan manusia ditunjang sepenuhnya oleh perangkat yang serba canggih dan serba digital. Hanya saja, sangat ironi ketika semua piranti penunjang segala aktivitas manusia telah begitu canggih dan modern, tetapi mental manusia penggunanya masih analog. sehingga dapat dibayangkan terjadinya ketimpangan di sana sini. Dan, salah satu solusinya adalah menciptakan manusia digital agar mampu mengimbangi teknologi digital tersebut.

Manusia digital adalah adalah manusia yang memiliki bilangan biner sebagai sistem transformasi atas potensi spiritualnya, yaitu yang berbasis pada angka nol dan satu. Apabila ini terwujud, maka akan lahir sebuah peradaban manusia tertinggi yang memiliki kemampuan IPTEK DIGITAl dan IMTAQ DIGITAL. Saat itulah generasi emas akan lahir di permukaan bumi ini. ${ }^{2}$

Oleh karena itu, diperlukan langkah-langkah nyata agar dapat menciptakan manusia digital dalam mengimbangi kecanggihan teknologi digital. Tentu saja langkah-langkah yang paling kongkrit saat ini adalah menajamkan peran dan fungsi lembaga-lembaga pendidikan yang sekarang ini dilihat miring oleh sebahagian orang. Pandangan miring ini disebabkan karena dunia pendidikan sedikit banykanya telah jauh dari harapan masyarakat. Banyaknya tawuran, perkelahian antarpelajar, dan bahkan maraknya pemakai obat-obat terlarang yang notabene dilakukan oleh para pelajar. Di sinilah letak peran lembaga pendidikan untuk kembali mereformulasi dan merevitalisasi format dan perwajahan pendidikan agar tidak hanya mengedepankan indoktrinasi kognitif dan psikomotor dengan mengabaikan aspek afektif peserta didik. Dengan kata lain, lembaga pendidikan terlalu mengejar kecerdasan intelektual dan melupakan sisi kecerdasan emosional dan spritual peserta didik. Akibatnya, dunia pendidikan mengalami kekaburan makna, kehilangan cita rasa, bahkan menjadi lembaga pendidikan yang tidak mendidik.

Oleh karena itu, dalam tulisan ini penulis akan mencoba mengangkat sebuah agenda penting untuk diejawantahkan dalam memoles kembali perwajahan dunia pendidikan dengan menitikberatkan pembahasan tentang peranan pendidikan Islam dalam menumbuhkan kecerdasan emosional peserta didik.

${ }^{2}$ Ary Ginajar Agustian, Rahasia Sukses Membangkitkan ESQ Power Sebuah Inner Journey Melalui Al-Ihsan, (Cet. V ; Jakarta : Penerbit Arga, 2004) halaman sampul 


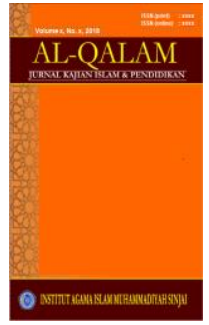

AL-QALAM

Jurnal Kajian Islam \& Pendidikan

Volume 06 No 012014

ISSN (print) : 1858-4152

ISSN (online) :-

Homepage : http://journal.iaimsinjai.ac.id/index.php/al-qalam

\section{PEMBAHASAN}

\section{A. Pengertian dan Fungsi Kecerdasan Emosional}

Kecerdasan berasal dari kata cerdas yang secara harfiah bearti sempurna perkembangan akal budi pekertinya, pandai, dan tajam pikirannya. Selain itu cerdas dapat pula berarti sempurna pertumbuhan tubuhnya seperti sehat,dan kuat fisiknya. ${ }^{3}$ Sedangkan kata emosional berasal darui bahasa Inggris, yang berarti keibaan hati, suara yang mengandung emosi, pembelaan yang mengharukan, pembelaan yang penuh perasaan. ${ }^{4}$ Dalam pengertian yang umumnya digunakan, emosi sering diartikan dorongan yang amat kuat dan cenderung mengarah kepada hal-hal yang kurang terpuiji, seperti halnya emosi yang ada pada remaja yang sedang goncang. ${ }^{5}$ Selanjutnya, kecerdasan emosional mengalami perkembangan baru dan secara umum menggambarkan sebagai potensi psikologis yang bersifat positif yang perlu dikembangkan.

Daniel Goleman mengatakan bahwa kecerdasan emosional mengandung beberapa pengertian yaitu:

1. Kecerdasan emosi tidak hanya berarti bersikap ramah. Pada saat-saat tertentu diperlukan mungkin bukan sikap ramah, melainkan misalnya sikap tegas yang barangkali memang tidak menyenangkan, tetapi mengungkapkan kebenaran yang selama ini dihindari.

2. Kecerdasan emosi bukan berarti memberikan kebebasan kepada perasaan untuk berkuasa memanjakan perasaan, melainkan mengelola perasaan sedemikian sehingga terekspresikan secara tepat dan efektif, yang memungkinkan orang bekerja sama dengan lancar menuju sasaran bersama. ${ }^{6}$ Kecerdasan emosional lebih lanjut dapat diartikan kewibawaan, kepandaian dan ketetapan seseorang dalam mengelola diri sendiri dalam berhubungan dengan orang lain disekeliling mereka dengan menggunakan seluruh potensi psikologis yang dimilikinya seperti inisiatif dan empati, adaptasi, komunikasi, kerjasama, dan kemampuan persuasif yang secara keseluruhan telah mempribadikan pada diri seseorang. ${ }^{7}$

Potensi-potensi psikologis yang demikian itu secara fitrah telah dianugrahkan Tuhan kepada manusia. Gambaran secara utuh adanya potensipotensi psikologis serupa itu akan dapat dijumpai dalam kajian terhadap manusia dan kedudukannya sebagai insan. Kata insan terambil dari kata uns yang berarti

${ }^{3}$ W.J.S Poerwadarminta. Kamus Besar Bahasa Indonesia ( Cet., XII., Jakarta: Balai Pustaka, 1991), h. 211.

${ }^{4}$ Zakiah Daradjat, Pendidikan Islam dalam Keluarga dan Sekolah (Cet. I., Jakarta: Ruhama. 1984), h. 88.

${ }^{5}$ Ibid

${ }^{6}$ Daniel Goleman. Kecerdasan Emosi untuk Mencapai Puncak Prestasi, (Cet. III,. Jakarta: Gramedia Pustaka Utama.2000), h. 9.

${ }^{7}$ Ibid., h. 5 


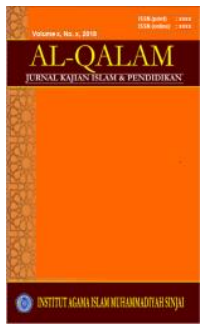

AL-QALAM

Jurnal Kajian Islam \& Pendidikan

Volume 06 No 012014

ISSN (print) : 1858-4152

ISSN (online) : -

Homepage : http://journal.iaimsinjai.ac.id/index.php/al-qalam

jinak, harmonis dan tampak. Dalam al-Quran insa digunakan untuk menunjuk pada manusia dengan seluruh totalitasnya, jiwa dan raga. Manusia yang berbeda antara seseorang dengan yang lain, akibat perbedaan fisik, mental dan kecerdasan. ${ }^{8}$ Dalam hal ini Musa Asy-Arie mengatakan bahwa kata insan berasal dari kata anasah yang memiliki melihat, mengetahui, minta izin, mengandung pengertian adanya kaitan manusia dengan kemampuan penalaran. Dengan penalarannya, ia dapat mengatahui apa yang benar dan apa yang salah dan terdorong untuk meminta izin menggunakan sesuatu yang bukan miliknya. ${ }^{9}$ Lebih lanjut Musa Asy-Arie mengatakan bahwa kata insan dalam Al-Quran disebut sebanyak 65 kali dalam 63 ayat yang digunakan untuk menunjukkan manusia sebagai makluk yang dapat menerima pelajaran dari Tuhan tentang apa yang tidak diketahuinya.

Untuk menggambarkan adanya kecerdasan emosional pada diri manusia, Al-Quran lebih menginformasikan adanya unsur nafs, qalb, ruh dan akal. Kata nafs memiliki macam-macam makna, terkadang diartikan totalitas manusia, dan terkadang diartikan sebagai apa saja yang terdapat di dalam diri manusia yang menghasilkan tingkah laku. Sedangkan qalb di dalam Al-Quran digambarkan sebagai wadah bagi pengajaran, kasih sayang, takut dan keimanan. Dengan demikian, qalbu menampung hal-hal yang didasari oleh pemiliknya. Wadah qalbu ini dapat diperbesar, diperkecil atau dipersempit. Ia dapat diperlebar dengan amalamal kebajikan serta jiwa. Selanjutnya, qalbu sebagai alat dilukiskan pula dengan kata fuad.

Membersihkan qalbu adalah salah satu cara untuk memperoleh pengetahuan. Imam Al-Ghazali memberi contoh mengenai qalbu sebagai pengetahuan serta cara mengisinya. Kalau kita membayangkan suatu kolam yang digali di tanah, maka untuk mengisinya dapat dilakukan dengan mengalirkan air sungai dari atas ke dalam kolam itu. Tetapi bisa juga menggali dan menyisihkan tanah yang menutupi mata air. Jika itu dilakukan, maka air akan mengalir dari bawah ke atas, untuk memenuhi kolam, dan air itu akan jauh lebih jernih dari air sungai yang mengalir dari atas. Kolam adalah qalbu, air adalah pengetahuan, sungai adalah pancaindra atau eksperimen. Sungai dapat dibendung atau ditutup, selama tanah yang berada di kolam dibersihkan agar air dari mata air memancar ke kolam. ${ }^{10}$ Sementara itu kata qalb digunakan Al-Quran untuk memahami dan menggambarkan sesuatu, dan daya untuk mengambil pelajaran dan kesimpulan serta hikmah. Sedangkan kata roh digunakan Al-Quran dalam makna yang beraneka ragam, sehingga sungguh sulit untuk menetapkan maknanya apalagi subtansinya. Ruh kadang diartikan sebagai wahyu yang dibawa oleh malaikat Jibril, sesuatu yang dianugrahkan Tuhan kepada orang mukmin dan berarti pula

${ }^{8}$ M. Quraisy Shihab, Wawasan Al-Quran (Cet. III., Bandung: Mizan, 1996), h. 280.

${ }^{9}$ Musa Asy-Arie, Manusia membentuk Kebudayaan Al-Quran (Cet. I ; Yorgayakarta : Lebaga Studi Fisafat Islam, 1992) h. 16

10 M. Quraisy Shihab, op. cit., h. 291 


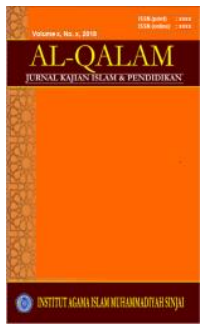

AL-QALAM

Jurnal Kajian Islam \& Pendidikan

Volume 06 No 012014

ISSN (print) : 1858-4152

ISSN (online) : -

Homepage : http://journal.iaimsinjai.ac.id/index.php/al-qalam

sebagai dukungan dan pengetahuan hati atau kekuatan batin, serta sesuatu yang dianugrahkan Tuhan kepada seluruh manusia, yakni unsur ilahiyah.

Jika dianalisis secara seksama, tampak bahwa istilah qalb, fuad dan akal lebih dekat kepada pengertian emosional, karena pada istilah-istilah tersebut beberapa hal yang terkait dengan potensi emosional dapat dijumpai, seperti, potensi kasih sayang, bermoral, bermain, takut berbuat salah, saling menolong, dapat bekerja sama dengan orang lain, dapat menerima pelajaran dari Tuhan dan dapat dikembangkan dapat dijumpai.

Istilah kecerdasan emosional dalam Islam dapat pula dijumpai dalam konsep lahir batin yang terdapat dalam ajaran Islam. Menurut petunjuk Al-Quran bahwa setiap ciptaan Tuhan seperti tumbuh-tumbuhan, binatang, air, udara, tanah, dan sebagainya memiliki jiwa. Selain mengisayaratkan adanya sifat kasih sayang dan kekuasaan Tuhan yang terdapat di balik ciptaan tersebut, juga memiliki jiwa atau emosi. Jika benda-benda tersebut diperlakukan dengan lembut, kasih sayang dan perhatian, maka semuanya itu akan memberikan manfaat kepada yang memerlukannya.

\section{B. Kecerdasan Emosional Dalam Islam}

Kecerdasan emosional sebagaimana digambarkan di atas terkait sifat-sifat terpuji yang muncul dari qalbu dan aql, yaitu sikap bersahabat, kasih sayang, empati, takut berbuat salah, keimanan, dorongan moral, bekerjasama dapat beradaptasi, berkomunikasi dan penuh perhatian dan kepedulian terhadap sesama mahkluk ciptaan Tuhan.

Dalam pendidikan Islam berbagai ciri yang mengarah kepada kecerdasan emosional tersebut terdapat pada pendidikan akhlak. ${ }^{11}$ Para pakar pendidikan Islam pada umumnya mengungkapkan bahwa tujuan pendidikan Islam adalah membina pribadi yang berakhlak. Sedangkan Ahmad Marimba mengatakan bahwa pendidikan Islam adalah bimbingan jasmani dan rohani menuju terbentuknya kepribadian utama menurut ukuran-kuran Islam. ${ }^{12}$

Berbagai pendapat tersebut di atas memperlihatkan bahwa pendidikan Islam di samping berusaha membina kecerdasan itelektual, keterampilan dan raganya, juga membina jiwa dan raganya. Juga membina jiwa dan hati nuraninya. Pembinaan intelektual dilakukan dengan memberikan mata pelajaran yang berkaitan dengan akal pikiran, dan pembinaan keterampilan dengan memberikan latihan-latihan mempergunakan berbagai peralatan. Sedangkan pembinaan jiwa dan hati ruhani dilakukan dengan membersihkan hati nurani dari penyakit separti sombong, tinggi hati, congkak, dendam, iri, dan sebagainya, serta dengan mengisinya dengan akhlak yang terpuji seperti ikhlas, jujur, kasih sayang, tolong menolong, bersahabat, silatulrahmi, berkomunikasi, saling mengingatkan dan

11 Abuddin Nata. Akhlak/Tasawuf, ( Jakarta: Usaha Iterprise, 1976), h.85.

12 Ahmad D. Marimba. Pengantar Filsafat Pendidikan Islam ( Cet. IV; Bandung AlMa`arif, 1980), h. 23. 


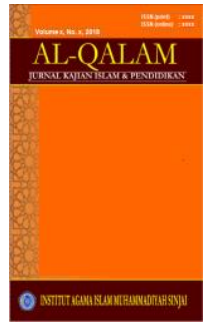

AL-QALAM

Jurnal Kajian Islam \& Pendidikan

Volume 06 No 012014

ISSN (print) : 1858-4152

ISSN (online) : -

Homepage : http://journal.iaimsinjai.ac.id/index.php/al-qalam

sebagainya. Ajaran akhlak yang demikian itu sangat diajarkan dalam pendidikan Islam. Ajaran-ajaran tersebut sudah sangat jelas dan sering diulang-ulang dalam berbagai kesempatan kajian Islam, mulai dari tingkat dasar sampai tingkat tinggi.

Namun masalahnya sekarang adalah, akhlak yang demikian itu sudah amat sulit ditumbuhkan. Pendidikan pada umumnya, termasuk pendidikan Islam pada saat ini cenderung berhasil membina kecerdasan intelekual, dan keterampilan, dan kurang berhasil menumbuhkan kecerdasan emosional. Hal ini terjadi kerena beberapa sebab sebagai berikut:

1. Pendidikan yang diselenggarakan pada saat ini cenderung hanya pengajaran, dan bukan pendidikan. Padahal antara pendidikan dan pengajaran dapat dintegrasikan.

2. Pendidikan pada saat ini sudah berubah dari orientasi nilai dan idealisme yang berjangka panjang, kepada yang bersifat materialisme, individualisme dan mementingkan tujuan jangka pendek.

3. Metode pendidikan yang digunakan tidak bertolak dari pandangan yang melihat manusia sebagai mahkluk yang paling mulia dan memiliki potensi yang bukan hanya potensi intelektual, tetapi juga potensi emosional.

4. Metode pendidikan yang diterapkan lebih melihat murid sebagai gelas kosong yang dapat diisi oleh guru dengan sekehendak hati, dan bukan melihatnya sebagai makhluk yang memiliki berbagai potensi yang harus ditumbuhkan, dibina, dikembangkan dan diarahkan sehingga berbagai potensi tersebut dapat tumbuh secara alami.

5. Pendidikan kurang mengarahkan siswanya untuk mampu merespon berbagai masalah aktual yang muncul di masyarakat, sehingga terdapat kesenjangan antara dunia pendidikan dengan dunia kehidupan di masyarakat.

\section{B. Peranan Guru Terhadap Pengembangan Kecerdasan Emosional dan Spiritual}

Guru adalah pendidik yang hanya ditemui anak setelah memasuki suatu lingkungan pendidikan formal/sekolah. Dengan kata lain guru merupakan pendidikan berikutnya setelah anak mendapatkan pendidikan dari orang tuanya. Oleh karena itu, pendidikan tersebut harus berkelanjutan agar diperoleh hasil yang maksimal. Terutama dalam hal pembinaan masalah kecerdasan emosional dan spiritual bagi anak, sehingga akan tampak bahwa guru memiliki peranan yang sangat besar terhadap pembinaan kecerdasan emosional dan spiritual anak.

Untuk melakukan pembinaan terhadap kedua kecerdasan tesebut, maka guru harus berupaya semaksimal mungkin untuk melakukan pembinaan jiwa agama. Hal ini disebabkan dengan pembinaan jiwa agama pada anak didik, akan melahirkan kecerdasan emosional dan spiritual sekaligus. Jadi, dapat dikatakan bahwa keberhasilan pembinaan kecerdasan emosional dan kecerdasan spiritual hanya dapat dapat tercapai jika nilai-nilai agama dapat tertanam ke dalam jiwa sanubari peserta didik. 


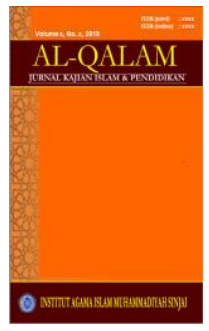

AL-QALAM

Jurnal Kajian Islam \& Pendidikan

Volume 06 No 012014

ISSN (print) : 1858-4152

ISSN (online) :-

Homepage : http://journal.iaimsinjai.ac.id/index.php/al-qalam

Oleh karena itu, fungsi guru sebagai tenaga pengajar, di samping menuangkan ilmu pengetahuan dalam otak peserta didik, juga diharapkan agar guru dapat membentuk jiwa agama peserta didik dengan tetap berpegang kepada kode etik guru, profesinya serta kepribadiannya agar dapat tertiru oleh peserta didiknya dalam segala hal seperti yang disampaikan oleh guru.

Dalam diri peserta didik hanya dituntut untuk terjadinya perubahan jiwa agama dalam bentuk tingkah laku. Perubahan itu dapat mengarahkan ke berbagai aspek kepribadian didik, baik fisik maupun psikis seperti berfikir, keterampilan, kecakapan, kebiasaan dan sikap. Hal ini sejalan dengan apa yang dikemukakan oleh Witheringtong dalam Chalija Hasan yang mengatakan bahwa :

Belajar adalah suatu perubahan di dalam kepribadian yang menyatakan diri sebagai suatu pola baru, daripada reaksi berupa kecakapan, sikap, kebiasaan, kepandaian atau suatu pengertian. ${ }^{12}$

Pemikiran tersebut di atas, dapat ditarik pemahaman bahwa perubahan yang terjadi pada diri peserta didik berupa perilaku yang baik menuju perilaku yang sempurna dan membentuk pola baru berupa kecakapan dan sikap terjadi manakala guru menempatkan kepribadian yang baik sebagai tiang utama dalam proses belajar mengajar baik di dalam kelas, sekolah maupun di masyarakat.

Sehubungan dengan fungsinya sebagai pengajar, pendidik, dan pembina, diperlukan berbagai peranan pada diri setiap guru. Peran guru ini akan senantiasa menggambarkan pola tingkah laku yang diharapkan. Terutama dalam berbagai interaksinya, baik dengan peserta didik, sesama guru maupun dengan yang lainnya, khususnya interaksi belajar mengajar.

Peters mengemukakan tiga tugas dan tanggung jawab seorang guru, yakni

a. Guru sebagai pengajar

b. Guru sebagai pembimbing

c. Guru sebagai administrator kelas. ${ }^{13}$

Selanjutnya, secara rinci peranan guru sebagai sebuah profesi yang harus dijalankan secara profesional sebagai berikut:
a. Informator
b. Organisator
c. Motivator
d. Fasilitator
e. Inisiator $^{14}$

Fungsi guru sebagai informator sangat penting karena gurulah sebagai pemberi infomasi bagi peserta didik dalam kegiatan akademik maupun umum. 1994) h. 86

${ }^{12}$ Chalija Hasan, Dimensi-dimensi Psikologi Pendidikan (Cet. I ; Medan : AL-Ikhlas,

${ }^{13}$ Nana Sujana, Dasar-dasar Proses Belajar Mengajar, (Cet. I ; Bandung : Sinar Baru Algesindo, 1995) h. 42

${ }^{14}$ Sardiman A.M, Interaksi dan Motivasi Belajar Mengajar, (Cet. I ; Jakarta : Rajawali, 1994) h. 142 


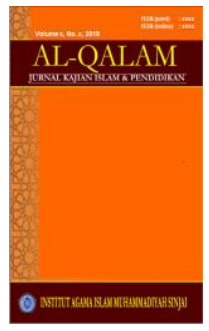

AL-QALAM

Jurnal Kajian Islam \& Pendidikan

Volume 06 No 012014

ISSN (print) : 1858-4152

ISSN (online) :-

Homepage : http://journal.iaimsinjai.ac.id/index.php/al-qalam

Sebagai organisator seorang guru memposisikan dirinya untuk mengatur, merencanakan, memprogramkan dan mengorganisasikan seluruh kegiatan proses belajar mengajar. Kemudian sebagai motivator, guru memberikan dorongan dan anjuran kepada peserta didiknya secara aktif dan kreatif. Guru yang berperan sebagai fasilitator dalam hal ini berusaha memberikan dan menyediakan fasislitas atau kemudahan dalam proses belajar mengajaar berlangsung secara positif, aktif dan efektif. Sedangkan sebagai inisiator, guru sebagai pencetus ide-ide dalam proses belajar mengajar. Ide-ide tersebut merupakan ide kreatif yang dapat dicontohi oleh peserta didiknya.

Peranan dan fungsi guru dalam proses belajar mengajar diperlukan adanya kemampuan dasar yang dimiliki oleh guru. Dalam hal ini Cooper mengemukakan empat kompetensi guru, yaitu :

a. Memiliki kemampuan belajar dan tingkah laku manusia

b. Memiliki pengetahuan dan menguasai bidang studi yang dibinanya

c. Memiliki sikap yang tepat mengenai diri sendiri, sekolah, teman sejawat.

d. Memiliki keterampilan teknik mengajar. ${ }^{15}$

Sedangkan Glasser mengatakan empat yang hendaknya dimiliki oleh guru, yaitu:

a. Menguasai bahan pelajaran

b. Kemampuan mendiagnosa siswa

c. Kemampuan melaksanakan proses pengajaran

d. Kemampuan mengukur hasil belajar siswa. ${ }^{16}$

Besarnya peranan yang disandang oleh guru dalam proses internalisasi nilai-nilai agama Islam ke dalam jiwa peserta didik melalui belajar mengajar, maka kompetensi yang disampaikan oleh kedua pakar di atas mutlak untuk dimiliki. Penguasaan materi bukan hanya kemampuan guru untuk menghafal materi, melainkan kemampuan untuk menyampaikannya di hadapan peserta didik, sehingga dapat menyentuh jiwanya.

Guru bertanggung jawab melaksanakan kegiatan pendidikan di sekolah dalam arti memberikan bimbingan dan pengajaran kepada para peserta didik. Tanggung jawab ini direalisasikan dalam bentuk pelaksanakan kurikulum, menuntun para peserta didik belajar, membina pribadi, watak dan jasmaniah peserta didik, menganalisa kesulitan belajar serta menilai kemajuan belajar para peserta didik. $^{17}$

Di samping itu, diperlukan pula profesi guru sebagai jabatan yang berlandaskan pada kode etik keguruan. Hal ini didasari dengan:

"Asas jiwa jabatan dan pengabdian guru menggerakkan dan mengatur tingkah lakunya, asas cita-cita, rasa hormat, dan bangga atas jabatan/prestasinya sebagai guru yang menjadi pendorong baginya untuk

\footnotetext{
${ }^{15}$ Nana Sujana, op cit, h. 18

${ }^{16} \mathrm{Ibid}$, h. 18

${ }^{17}$ Oemar Hamalik, Pendidikan Guru (Cet. I ; Jakarta : PT. Bumi Aksara, 2002) h. 38
} 
memperhatikan dan menaati norma-norma jabatannya, asas kebiasaan dan mengamalan-pengamalan di dalam melaksanakan tugas dan jabatnnya akan memperkuat kekaryaan profesinya dan upaya-upaya yang terusmenerus dalam meningkatkan mutu profesi, mengembangkan kepribadian dan kehidupan sosialnya sehingga benar-benar menjadi guru pendidik dan pengajar yang profesional. ${ }^{18}$

Manakala seluruh fungsi dan peranan guru dilakukan dalam seluruh sikap, sifat dengan penuh rasa tanggung jawab, maka optimalisasi penanaman nilai-nilai agama ke dalam sanubari peserta didik akan tercapai. Konsep-konsep tentang fungsi dan peranan guru sangat ideal, namun implementasi dan penerapannya sangat sensitif karena dipengaruhi oleh faktor internal guru maupun eksternal yang mempunyai corak beraneka ragam di tengah laju perkembangan sosial yang kompleks dan dinamis di era modern.

Oleh karena itu, itu pada diri guru hendaknya tertanam keinginan untuk menjalankan tugas dan tanggung jawabnya dengan baik dan peranan yang dibebankan kepadanya dalam proses belajar mengajar ditempatkan pada waktunya, sehingga internalisasi jiwa agama dalam diri anak dapat berjalan dengan efektif dan efisien melalui iklim proses belajar mengajar yang dilakukan oleh guru di sekolah.

Berdasarkan hal tersebut, dapat dipahami bahwa untuk mencapai suatu kecerdasan emosional dan kecerdasan spriritual pada anak didik, maka eksistensi guru yang sadar akan profesi dan kompetensinya merupakan suatu hal yang mutlak. Hal ini disebabkan untuk menanamkan jiwa agama yang akan berbias kepada kecerdasan emosi dan spiritual anak, dilakukan melalui proses interaksi guru dengan peserta didik di sekolah, baik melalui proses belajar mengajar maupun bentuk lain yang dapat mendukung tercapainya.

\section{KESIMPULAN}

Berdasarkan pada pembahasan yang telah dikemukakan sebelumnya, dapat disimpulkan bahwa kecerdasan emosi tidak hanya berarti bersikap ramah. Pada saat-saat tertentu diperlukan mungkin bukan sikap ramah, melainkan sikap tegas dalam hal-hal yang tidak sesuai dengan peraturan atau hal-hal yang tidak menyenangkan dalam rangka mengungkapkan kebenaran yang selama ini dihindari.

Dalam konsteks pendidikan Islam kecerdasan emosi dan spiritual adalah terwujudnya keadaan jiwa dan hati nurani yang bersih dari penyakit separti sombong, tinggi hati, congkak, dendam, iri, dan sebagainya. Cara mengisinya lewat konten pendidikan agama yang ditanamkan ke dalam jiwa peserta didik

${ }^{18}$ H. Abdurrahman, Pengelolaan Pengajaran, (Cet. IV ; Ujung Pandang, Bintang Selatan, 1994) h. 68 


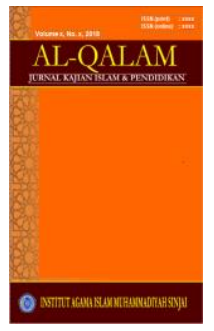

AL-QALAM

Jurnal Kajian Islam \& Pendidikan

Volume 06 No 012014

ISSN (print) : 1858-4152

ISSN (online) : -

Homepage : http://journal.iaimsinjai.ac.id/index.php/al-qalam

yang dilakukan oleh guru. Di sinilah posisi strategis seorang guru yang tidak dapat digantikan oleh teknologi apapun.

Guru harus menyadari bahwa di samping tanggung jawab untuk proses belajar mengajar dalam membentuk intelektualitas anak didik, ia juga harus berperan penuh dalam menanamkan kecerdasan emosional dan kecerdasan spiritual pada anak didik. Indikatornya adalah lahirnya peserta didik yang memiliki sikap-sikap terpuji seperti ikhlas, jujur, kasih sayang, tolong menolong, bersahabat, silatulrahmi, berkomunikasi, saling mengingatkan dan sebagainya yang sesuai dengan ajaran-ajaran Islam.

\section{DAFTAR PUSTAKA}

Agustian, Ary Ginajar, Rahasia Sukses Membangkitkan ESQ Power Sebuah Inner Journey Melalui Al-Ihsan, Cet. V ; Jakarta : Penerbit Arga, 2004

Asy-Arie, Musa Manusia membentuk Kebudayaan Al-Quran, Cet. I ; Yorgayakarta : Lebaga Studi Fisafat Islam, 1992

Daradjat, Zakiah. Pendidikan Islam dalam Keluarga dan Sekolah, Cet. I., Jakarta: Ruhama. 1984

Goleman. Daniel, Kecerdasan Emosi untuk Mencapai Puncak Prestasi, Cet. III,. Jakarta: Gramedia Pustaka Utama.2000

H. Abdurrahman, Pengelolaan Pengajaran, Cet. IV ; Ujung Pandang, Bintang Selatan, 1994

Hamalik, Oemar Pendidikan Guru, Cet. I ; Jakarta : PT. Bumi Aksara, 2002

Hasan, Chalija, Dimensi-dimensi Psikologi Pendidikan, Cet. I ; Medan : ALIkhlas, 1994

Nata. Abuddin. Akhlak/Tasawuf, Jakarta: Usaha Iterprise, 1976

M, Sardiman A. Interaksi dan Motivasi Belajar Mengajar, Cet. I ; Jakarta : Rajawali, 1994

Marimba. Ahmad D. Pengantar Filsafat Pendidikan Islam, Cet. IV; Bandung AlMa`arif, 1980

Poerwadarminta. W.J.S. Kamus Besar Bahasa Indonesia, Cet., XII., Jakarta: Balai Pustaka, 1991

Shihab, M. Quraisy. Wawasan Al-Quran, Cet. III., Bandung: Mizan, 1996

Sujana, Nana. Dasar-dasar Proses Belajar Mengajar, Cet. I ; Bandung : Sinar Baru Algesindo, 1995 